\title{
The Equal Rights Amendment and the Military
}

Until November 8, 1967, women could not, by law, constitute more than two percent of the total military personnel in the armed forces. ${ }^{1}$ Even with the lifting of this statutory bar, women are not yet an integral part of the armed services, comprising only 1.9 percent of the total personnel. ${ }^{2}$ This low level of participation undoubtedly reflects a widespread feeling among women as well as men that combat is essentially a male activity, but it may also be the result of the numerous statutes, regulations and informal policies that disfavor women at every level of the military hierarchy. ${ }^{3}$ Many of these sex distinctions have been discarded during the last decade in response to a resurgent concern for the rights of women.* Others persist, however, reflecting the continuing belief of military and legislative decision-makers that generally women are inadequate or inappropriate substitutes for men in many military positions. ${ }^{5}$

The prevailing policy of the military, as a representative of the Air Force expressed it, is that personnel policies and procedures should be made essentially the same for men and women "except where there are legitimate rational reasons to do otherwise." "This test may not even

1. See, e.g., 10 U.S.C. $\$ 3209$ (1964), as amended, 10 U.S.C. $\$ 3209(\mathrm{~b})$ (1970); Act of Aug. 10, 1956, ch. 1011 , 70A Stat. 298, repealed by Act of Nov. 8, 1967 , Pub. L. No. 90-130, § 1(b), 81 Stat. 376; Act of Aug. 10, 1956, ch. 1041, 70.1 Stat. 299, repealed by Act of Nov. 8, 1967, Pub. L. No. 90-130, \$ 1(16), 81 Stat. 376. The two percent limit still exists in the Army, maintained by regulation. 32 C.F.R. $\$$ 580.4(b) (1972).

2. Central All-Volunteer Force TASK Force, Utilization of Mfiltrary Wosies vi (1972) [hereinafter cited as TASK FORCE REPORT]. The number of women in the Air Force has doubled in the past five years, whereas the number of women in the Marines has shrunk by thirty percent. Hearings Before the Special Subcomm. on the Utilization of Manpower in the Military of the House Comm. on Armed Services, 92d Cong., 1st \&. 2d Sess. 12439 (1972) [hereinafter cited as Utilization Hearings].

3. The Navy has compiled twenty-two pages of computer printout that list sections of the United States Code which distinguish between Navy men and vomen. Telephone Interview with Captain Robin Quigley, Assistant Chief of Naval Personnel (Women). Nov. 20, 1972.

4. The services are carrying out comprehensive reviews of the regulations which make distinctions between the sexes. Telephone Interviews with Brig. General Jeanne M. Holm. Director of Women in the Air Force, Nov. 1, 1972 (on MIarch 1, 1973, General Holm assumed her new position as Director Secretary of the Air Force Personnel Council). and Captain Robin Quigley, supra note 3. Congress eliminated a considerable number of statutory distinctions in 1967, see Pub. L. No. 90-130, II Stat. 375 (1967); note 1 supra; and the courts have also struck down a varicty of policies, sec, e.g., notes 8 \&. 140 infra.

5. This attitude was bluntly expressed by General Lewis B. Hershey, former Director of the Selective Service System:

There is no question but that women could do a lot of things in the military service.

So could men in wheelchairs. But you couldn't expect the services to want a whole company of people in wheelchairs.

Coje, The Restricted Unrestricted Line Officer: The Status of the Nay's Woman Line Officer, Naval WaR Collece Rev. (March 1972), reprinted in Utilizotion Hearings, supro note 2 , at 12477 .

6. Utilization Hearings, supra note 2, at 12451 (testimony of General Holm). 
satisfy existing judicial standards. The Supreme Court recently divided evenly on the issue of whether sex is a suspect classification? ${ }^{7}$. In Frontiero v. Richardson, ${ }^{8}$ four Justices declared that "classifications based upon sex, like classifications based upon race, alienage, or national origin, are inherently suspect, and must therefore be subjected to strict judicial scrutiny."9 Lacking clear direction from the Supreme Court, several state and lower federal courts appear to be developing an intermediate standard of scrutiny in reviewing sex-based classifications. ${ }^{10}$ Congress may have obviated resolution of this issue by passing the Equal Rights Amendment, which, if ratified by the states, would require an even more stringent standard than advocated by the four justices in Frontiero. This Note will discuss some of the more significant distinctions between men and women that still exist in the military, and assess the constitutionality of these differences under the proposed Amendment.

\section{Interpretation of the Equal Rights Amendment}

The Equal Rights Amendment (ERA) states that:

Equality of rights under the law shall not be denied or abridged by the United States or by any State on account of sex. ${ }^{11}$

7. Previously, in Reed v. Reed, 404 U.S. 71 (1971), the Supreme Court appearcd to have used a rational basis test to invalidate a state statute which provided that when equally qualified male and female applicants apply for appointment as administrators of an estate, the man must be chosen. However, since the requirements of the rational basis test were not satisfied, the Court did not have to reach the issue of whether the strict scrutiny test could have been applied.

8. 41 U.S.L.W. 4609 (U.S. May 14, 1973). The Court invalidated 37 U.S.C. $\$ \$ 401,408$ (1970) and 10 U.S.C. $\$ \$ 1072,1076(1970)$, which provided that married male members of the armed services automatically receive increased quarters allowances and medical and dental benefits for their spouses, whereas married fernale members must first cstablish that their husbands are, in fact, dependent on then for more than one-half of their support. It ruled that these provisions constituted discrimination in violation of the Due Process Clause of the Fifth Amendment.

9. Id. at 4612. Justices Brennan, Douglas, White and Marshall reached this conclusion. Justices Powell, Burger and Blackmun concurred in the judgment of the Court, but would have based the decision on Reed without reaching the issue of stuspect classiff. cation. In a single sentence concurrence, Justice Stewart did not explicitly side with either of these approaches. He concluded that the statute in question worked "an ill. vidious discrimination in violation of the Constitution," id. at 4618 , a term traditionally reserved for strict scrutiny cases, but he also cited Reed, indicating sympathy for the view expressed by the other Justices in concurrence.

10. See, e.g., United States v. York, 281 F. Supp. 8 (D. Conn. 1968); Commonwealth v. Daniel, 430 Pa. 642, 243 A.2d 400 (1968); Note, The Sexual Segregation of American Prisons, 82 Yale L.J. 1229, 1246.48 (1973).

11. H.J. Res. 208, 92d Cong., lst Sess., 117 Conc. Rec. H 9392 (daily cd. Oct. 12, 1971); S.J. Res. 8, 92d Cong., $2 d$ Sess., 118 CoNc. REc. S 4162 (daily ed. March 22, 1972). The House approved H.J. Res. 208 in its original form by a vote of $354-23$. 117 Cowo. Rec. H 9392 (daily ed. Oct. 12, 1971). The Senate debated the issue in March 1972 and approved the joint resolution by a vote of $84-8$. 118 Conc. REC. S 4612 (daily ed. March 22, 1972). The Amendment has been submitted to the states for ratification. 
Because of the breadth and vagueness of this language, courts would undoubtedly look to legislative history in interpreting the Amendment. ${ }^{12}$

An examination of congressional hearings and debates reveals that Congress adopted a strict interpretation of the Amendment, a position originally propounded by Professor Thomas Emerson and three students from the Yale Law School. ${ }^{13}$ Under this approach sex could not be a factor in determining the legal rights of women or men. To achieve the values of group equality and individual self-fulfillment, the Amendment would have to be applied comprehensively:

The issue under the equal rights amendment cannot be benefit or detriment, reasonable or unreasonable classification, strict scrutiny, compelling reasons or the demands of administrative expediency. Equality of rights simply means that sex is not a factor. ${ }^{14}$

However, the Emerson interpretation does incorporate two important exceptions to this rule of strict equality. First, the Amendment would not preclude legislation which takes into account a physical characteristic unique to one sex.. ${ }^{15}$ The exception is, however, limited to physical characteristics-and does not extend to psychological, social, or other perceived sex differences-because only physical characteristics can accurately be described as unique to one sex.. ${ }^{10}$ Distinctions justified by this exception would have to be closely scrutinized to insure that they were legitimate and narrowly drawn. ${ }^{17}$

12. It has been argued that, since the states will be ratifying the language of the Amendment itself and not a committee report, courts would look solcly to the words alone, and not to the legislative history, in applying the Amendment. 118 CoNic. REC S 4377 (daily ed. March 21, 1972) (remarks of Senator Stennis); Hearings on H.J. Res. 208 Before Subcomm. $f$ of the House Committee on the Judiciary, $92 \mathrm{~d}$ Cong., lst Sess. 75-76 (1971) (remarks of Senator Ervin) [hercinafter cited as Hearings]. However, courts have frequently utilized legislative history in developing a framework for the application of constitutional amendments. See, e.g., the extensive use of legislative history by the courts in interpreting the Fourteenth Amendment: Hurd v. Hodgc, 334 U.S. 24, 32.33 (1948); Shelley v. Kramer, 334 U.S. 1, 23 (1948); Slaughter-House Cases, 83 U.S. (1G Wall.) 36,81 (1873).

13. Brown, Emerson, Falk \& Freedman, The Equal Rights Amendment: A Constilutional Basis for Equal Rights for I'omen, 80 YALE L.J. 871 (1971). Other possible in. terpretations of the Amendment-including the "rationsl basis" test, the "striet scrutiny" analysis used to test racial classifications, and an absolute standard admitting of no exceptions-were considered and rejected by Congress. See Note, supra note 10, at 12:54.61.

14. Hearings, supra note 12, at 402 (testimony of Professor Emerson). See also Emerson, In Support of the Equal Rights Amendment, 6 HARv. Civ. RIGirs.Civ. Lib. L. REv. 225 (1971).

15. Brown, Emerson, Falk \& Freedman, supra note 13, at 893. See also Hearings, supra note 12, at 402 (testimony of Professor Emerson).

16. Brown, Emerson, Falk \& Freedman, supra note 13, at 893.

17. Professor Emerson and his associates identified six factors which a court should balance in determining whether the necessary close, direet, and narrow relationship exists between the unique physical characteristic and the regulation at issuc: (I) the proportion of women or men who actually have the characteristic in question; (I) the rela- 
Second, the Emerson framework stresses that the ERA would have to be harmonized with the overall structure of the Constitution. Laws or administrative action implementing the ERA would have to be ap. plied in a manner consistent with such preexisting constitutional rights as individual privacy. ${ }^{18}$

The Emerson interpretation was praised by the two principal proponents of the amendment, Congresswoman Martha Griffiths ${ }^{10}$ and Senator Birch Bayh, ${ }^{20}$ and referred to with approval in the Congressional Reports. ${ }^{21}$ According to ERA opponent Senator Sam Ervin, the Yale Law Journal article in which that interpretation is set forth will constitute "primary legislative history" of the Amendment. ${ }^{22}$ More generally, the framework outlined in the legislative history parallels the Emerson interpretation in every relevant respect. ${ }^{23}$

tionship between the characteristic and the problem to be solved; (3) the proportion of the problem attributable to the unique physical characteristic; (4) the proportion of the problem eliminated by the solution; (5) the availability of less drastic alternatives; (6) the importance of the problem ostensibly being solved, as compared with the costs of the least drastic solution. $1 d$. at $894-96$.

Examples of laws which could be permissible are those which concern wet nurses and sperm donors, establish medical leave for childbearing, and determinc paternity. $l_{l}$.; Hearings, supra note 12 , at 402.

18. Hearings, supra note 12 , at 402 (testimony of Professor Emerson). Concerning the right of privacy as it has been developed before and after congressional passage of the ER.A, sec Roe v. Wade, 93 S. Ct. 705 (1973); Eisenstadt v. Baird, 405 U.S. 498 (1972); Griswold v. Connecticut, 381 U.S. 479 (1965).

19. Congresswoman Griffiths sent a copy of the Yale Law Journal article by pro. fessor Emerson and his associates, supra note 13, to all members of the Housc, saying:

It will help you understand the purposes and effects of the ERA . . . The

article explains how the ERA will work in most areas of the law.

118 CoNc. REc. $S 4250$ (daily ed. March 20, 1972).

20. Senator Bayh inserted a copy of the article in the Congressional Record, declaring it to be "a masterly piece of scholarship." Id.

21. The Separate Views section of the House Report, which prevailed over the ma. jority position on the floor of the House, see Note, supra note 10 , at $1256 \mathrm{n} .142$, and was endorsed by the Senate Report, see S. REP. No. 92.689, 92d Cong., $2 \mathrm{~d}$ Scss. 11 (1972), stated:

The basic premise of [the ERA] is a simple one. As stated by Professor Thomas Emerson of Yale University, .... the [Amendment] is based on the fundamental prop. osition that sex should not be a factor in determining the legal rights of women or of men.

H.R. REP. No. 92-359, 92d Cong., 1st Sess. 6 (1971). Representative Don Edwards, allthor of the Separate Views, characterized Professor Emerson's comments as "entering il new level of understanding about what the enactment of a constitutional amendmcnt would in effect do to the quality of life in America." 118 CoNG. REC. $S 4264$ (daily ed. March 20, 1972).

22. 118 ConG. Rec. S 4264 (daily ed. March 20, 1972).

23. The Congressional Reports echoed Professor Emerson's basic propositions that "sex should not be a factor in determining the legal rights of women or of men," H.R. REP. No. 92-359, supra note 21 , at 6 (Separate Views), and that "the law must deal with the individual attributes of the particular person and not with stereotypes or overclassifications based on sex." Id. at 7, cited with approval in S. REP. No. 92.689, supra note 21 , at 12 .

The Reports also endorsed his two exceptions. The Senate Report stated that the ERA "would not prohibit reasonable classifications based on characteristics that are unique to one sex," S. REr. No. 92-689, at 12, and the Amendment's supporters stressed that only physical characteristics fit within this proviso. See 118 CoNG. REc. S 4550 


\section{Application of the Equal Rights Amendment}

Despite commentary regarding the effect of the ERA on the draft, ${ }^{2 *}$ little attention has been paid to the momentous changes that it would require in the structure and policies of the armed services themselves."s Although the legislative history does not include a detailed examination of this problem, there was sufficient discussion to warrant the conclusion that Congress intended the Amendment to be fully applied to the military. ${ }^{20}$

It is well established that a citizen does not relinquish his constitu-

(daily ed. March 22, 1972) (remarks of Senator Bayh, characterizing the views of the majority of the Senate Judiciary Committee as well as his own); Hearings, supra note 12, at 40 (remarks of Congresswoman Griffiths). The Senate Report also declared that the "constitutional right of privacy established by the Supreme Court in Griswold v. Connecticut" would limit the rule of complete sexual integration with respect to such facilities as public toilets and sleeping quarters at public institutions. S. REP. No. 92-689, at 12. In response to Senator Ervin's claim that a special privacy exception had to be incorporated into the ERA itself to insure such limitation, Senator Bayh quoted from the testimony of Professor Norman Dorsen of New York University Law School:

It is sometimes claimed that an amendment would require all public restrooms to

be integrated, along with the sleeping quarters of prisons and other public in-

stitutions. This, of course, is nonsense. The Constitution must be read as a whole, and an equal rights amendment would fit into the total constitutional frametiork. To this, Senator Bayh added:

It is unequivocally clear in the Report of the Committe on the Judiciany that

this is the intention of the Senate. It is equally clear bcause jentical language is

in the House report, that this is the intention. The right 10 privacy will continuc

to exist and will be fully protected after the equal rights amendment is ratified. 118 CoNg. REC. S 4544-45 (daily ed. March 22, 1972). See also note 78 infra.

In addition to the two exceptions explicitly outlined by Emerson and accepted by the proponents of the Amendment, the House and Senate Reports refer to the traditional power of the State to regulate cohabitation and sexual activity by unmarried persons. See H.R. REP. No. 92-359, supra note 21, at 7 (Separate Vievis), quoted urith approval in S. REP. No. 92-689, at 12. Apparently the authors believe that this police power, rather than being struck down by the Amendment, would be balanced against it. This view, however, is inconsistent with the remainder of the Emerson interpretive framework that Congress adopted, which limits the exception to accommodate constitutional rights only. See pp. 1535-36 supra. Professor Emerson does note that societal "mores" regarding existing attitudes towards relations between the sexes may have some importance in defining the scope of the constitutional right to privacy, Brown, Emerson. Falk \& Freedman, supra note 13, at 902 , but it is only in this context that the above references to state regulatory power should be used by the courts.

24. See Hale and Kanowitz, Women and the Draft: A Response to Critics of the Equal Rights Amendment, 23 Hastixcs L.J. 199 (1971).

25. The military was discussed briefly in Brown, Emerson, Falk \& Frecdman, supra note 15. Senator Ervin placed several excerpts from this part of the article into the Congressional Record. Commenting on the use of the article by the proponents of the Amendment, he stated:

Thus the supporters of the amendment feel that it will have the following. effect on the military and I agree with them. No clearer or morc unique history of legis-

lative intent can be presented of the amendment and the military because both

the opponents and the proponents agree on the amendment's cffect in this ares.

118 CoNG. Rec. S 4576 (daily ed. March 22, 1972).

26. The legislative history of the Amendment reveals that Congress struggled with the problem of requiring military service, particularly combat duty, for vomen. For example, when Senator Ervin attempted to guarantee that passage of the Amendment would not affect Congress' right to bar women from compulsory conseription or from service in combat units, his amendments were soundly defeated. See 118 CoxG. REC S 4395, S 4408 (daily ed. March 21, 1972). 
tional rights when he enters the armed forces. ${ }^{27}$ Service personnel are entitled to all constitutional rights except those which are expressly withheld by the Constitution or by necessary implication inapplica. ble. ${ }^{28}$ Rights have been said to be "impliedly inapplicable" when they conflict with the requirements of "military necessity" by seriously impairing the discipline and morale of the armed forces. ${ }^{20}$

The doctrine of military necessity has been considered in a number of decisions involving due process and First Amendment rights. ${ }^{30}$ In each of these cases the rights involved were balanced against the peculiar needs of the military. Such accommodation is required even when fundamental constitutional rights are involved, ${ }^{31}$ because the doctrine of military necessity is also of constitutional dimension, deriving from the authorization to raise and maintain armed forces..$^{32}$ As such, even those changes required by the ERA would have to be balanced against the military's need to maintain a minimum level of discipline within the services..$^{33}$ However, only those measures which would substantially impair discipline or morale-which would, in other words, effectively deprive Congress of its ability to raise and maintain combat forceswould present a sufficiently direct conflict between the two constitutional doctrines to require accommodation. ${ }^{34}$ Moreover, no conflict

27. Burns v. Wilson, 346 U.S. 137 (1953); United States v. Tempia, 16 U.S.C.M.A. 629, 37 C.M.R. 249 (1967); United States v. Jacoby, 11 U.S.C.M.A. 428, 29 C.M.R. 244 (1960); Whether or not constitutional claims under the ERA could be brought in civil as well as military courts would depend on a variety of factors, see Mindes v. Seaman, 459 F.2d 197 (5th Cir. 1971), but in any case the same standards would be applied. The Court of Military Appeals considers itself "bound by the Supreme Court on yuestions of constitutional import." United States v. Tempia, 16 U.S.C.M.A. 629, 643, 37 C.M.R. 249, 263 (1967) (concurring opinion). See note 31 infra.

28. United States v. Jacoby, 11 U.S.C.M.A. 428, 29 C.M.R. 244 (1960).

29. Burns v. Wilson, 346 U.S. 137, 140 (1953); United States v. Howe, 17 U.S.C.M.A. $165,173,37$ C.M.R. 429,437 (1967).

30. See, e.g., Dash v. Commanding General, 307 F. Supp. 849 (D. S.C. 1969); United States v. Howe, 17 U.S.C.M.A. 165, 37 C.M.R. 429 (1967); United States v. Tempia, 10 U.S.C.M.A. 629, 37 C.M.R. 249 (1967).

31. The existing cases have not had to determine whether this balancing process is always required when military necessity is involved, because they have dealt with coun. tervailing constitutional rights which were not absolute, i.e., they permitted a balance against even nonconstitutional government interests. See, e.g., Dash v. Commanding Gen. eral, 307 F. Supp. 849, 853 (D. S.C. 1969): "[W]here First Amendment rights are in. volved, whether of civilian or serviceman, the issue always involves the balancing by the Courts of the competing private and public interests at stake in the particular circumstances."

32. Miller, A Long Look at Article 15, 28 MiL. L. Rev. 37, $51-52$ (1965). The constitutional provisions authorizing the raising and regulation of armed forces are U.S. CoNSr. art. I, $\S 8$, cls. $12,13,14,18$.

33. See p. 1536 supra.

34. See Miller, supra note 32 , at 52 (emphasis added):

To maintain discipline and thus to maintain an effective army, it is necessary for Congress to strike a balance between the rights of individuals and the methods by which the services are to maintain discipline. In so doing, the balance struck must sometimes infringe upon normal civilian individual rights. When our continued national existence is at stake, individual rights guaranteed by the Constitution may 
could be said to exist if the military's overriding disciplinary needs could be satisfied through means less drastic than the creation of sexbased classifications. ${ }^{35}$

The vast majority of sexual classifications that presently exist cannot be justified by legitimate military necessity or by any of the other recognized exceptions to the ERA. This Note will examine existing military policies ${ }^{36}$ and regulations to determine the changes necessary to bring them into conformity with the Amendment.

\section{A. Getting In}

\section{Enlistment}

Although the statutory limit on the number of women in the service has been lifted, ${ }^{37}$ the Secretary of each branch of the service can prescribe the authorized strength of female enlisted and officer personnel..$^{38}$ For a variety of reasons, including inadequate training facilities, $^{39}$ the Secretaries have chosen to limit the number of women in the military to less than two percent of all service personnel..0

In all the services women are subject to more exacting enlistment criteria relating to minimum age and parental consent requirements. ${ }^{41}$

have to give way, for it is not possible to lose the nation and yet preserve the Constitution.

See also Warren, The Bill of Rights and the Military, 37 N.Y.U. L. REv. 181, 183 (1902), in which the former Chief Justice equated "military necessity" with "national survival:"

35. Certainly the rights granted by the ERA, stated as they are in absolute terms. must be assigned at least as high a value as other individual liberties. In the case of the latter, it is well-settled that only interests and needs which cannot be satisfied in any other manner can be balanced against them. Lewis, Freedom of Speech-An Examination of the Givilian Test for Constitutionality and It Application to the Military, 41 MiL. L. REV. 55, 79 (1968). See also Miller, supra note 32, at 54 , in which the author limits the requirements of military necessity to "the minimum power essential to enforce discipline in the armed forces (and thereby preserve national sceurity) ...."

36. This Note deals with the effect that the ERA would have on four services: the Army, the Navy, the Marines, and the Air Force. It does not deal with the special problems of the Coast Guard, the National Guard, or the Reserves, although most of the analysis below is relevant to these services as well.

37. See note 1 supra.

38. See, e.g., 10 U.S.C. $\S \S 3209,3215,8208,8215$ (1970).

39. Utilization Hearings, supra note 2, at 12444 (testimony of $\mathrm{Gen}$. Bailcy). The lact that women today comprise only about 13,000 of the more than one million Army personnel, id. at 12440, is justified in part by the fact that all basic training of female enlistees in the Army takes place at Fort ArcClellan, Alabama, which has a capacity of only 6,000-enlistees. See Watson, Fact Sheet, Expansion of the Women's Army Corps, on file with the Yale Law Journal. The Commandant of the Marine Corps has estab. lished one percent of the total Marine enlisted strength as a goal for the strength of enlisted women. One of the reasons cited for this ceiling is the lack of training facilitics. Utilization Hearings, supra note 2, at 12458 (testimony of Colonel Sustad).

40. See p. 1533 supra.

41. 10 U.S.C. $\$ 505(1970)$ sets out the qualifications for original enlistment in the Army, Navy, Air Force, Marine Corps, and Coast Guard. Men applying must be not less than 17 years of age, whereas women must be not less than 18. Writcen parental consent 
They must also have higher scores on mental aptitude tests and more educational credentials than their male counterparts. ${ }^{42}$ Although women in the Army are barred from strenuous training ${ }^{43}$ and from various occupational specialities which require "heavy" labor, 44 they must meet a minimum physical standard stated in more stringent terms than that imposed on males. ${ }^{45}$ Finally, men who have dependent children may enlist under the normal Army procedures, but women must first obtain a waiver. ${ }^{40}$

Most of these enlistment differentials are justified on a theory of sup. ply and demand: Since more women, but fewer men, apply than are desired by the services, the standards for women are set at higher levels. ${ }^{47}$ This reasoning, based as it is upon judgments concerning the use-

is necessary to enlist a male under the age of 18 or a female under the age of 21. Thesc distinctions are defended as a means of "protecting" young women from "making rash and immature" decisions and of providing the services "with a screening device by re. quiring wise and objective judgment of the interested parent or guardian." Utilization Hearings, supra note 2, at 12498 (testimony of General Bailey).

A bill to make the minimum age of enlistment in the armed forces the sanc for both males and females was introduced in Congress on October 4, 1971, H.R. 11064, 92d Cong., Ist Sess. (1971), and received great attention from the branches of the service. See, e.g., Utilization Hearings, supra note 2, at 12500 (testimony of Captain Quigley). However, it died in the Armed Services Committee of the House and would have to be reintroduced.

42. To enlist in the Army men need only to meet the educational requirements of the specific option for which they are enlisting, not all of which requirc completion of high school. Women, however, must possess either a high school diploma or certi. fication of passage of the equivalency exam. In addition, women are given a different battery of mental aptitude tests, and it is argued that since the scores are not comparable, the minimum qualifying scores are not required to be equal. Willians, Army Fact Sheet, Army Enlistment Standards for Men and Women, Aug. 7, 1972, on filc with the Yale Law Journal. An attorney in the office of the General Counsel of the Sccretary of Defense stated:

All of the services have indicated to me that in general the minimum standards on test results and educational level required in order for a person to cnlist or be an officer are generally higher for women than for men.

Speech by Carole L. Frings, DACOWITS Fall Meeting, Colorado Springs, Colorado, Nov. 12-16, 1972, at 11. See also TASK FORCE REPOKT, supra note 2, at 14.

43. See note 76 infra.

44. See p. 1547 infra.

45. The consistency with which minimum physical standards are applicd-with re. spect to both men and women-may be open to doubt. But the regulations are stated in undeniably different terms. For example, potential women Army enlistees must be able to perform with maximum effort for "indefinite" periods, to take "long" marches, and to withstand long periods of standing. Men are only incligible if they have de. fects which would prevent "moderate" marching, and their ability to perform with maximum effort need only be for "long" rather than "indefinite" periods. The psychiatric standards for women are also more stringent. See Appendix VIII, Physical Pro. file Functional Capacity Guide, C22, AR 40-501, June 19, 1968 (in document dated Aug. 7, 1972), on file with the Yale Law Journal. In the Marine Corps the physical profile for entry of women is also higher than that required for men. The Navy and Air Force have the same physical profile requirements for females as for males. 1Ask FORCE REPORT, supra note 2, at 16.

46. TASK FORCE REPORT, supra note 2, at 17. This differential also exists in the Marine Corps. Id. Until recently, both services also required a waiver for all married women, id., but the Army cancelled this restriction, effective April 20, 1973. N.Y. Times, March 27, 1973 , at 26 , col. 3 .

47. Speech by Frings, supra note 42 , at 11 . 
fulness of an entire sex rather than of the individuals that comprise it, would be unacceptable under the ERA. ${ }^{\text {s }}$ Instead, minimum standards with regard to age, education, and mental and physical ability would have to be identical for men and women. Both sexes would have to be subjected to the same tests, except to the extent that certain medical criteria would be permitted to deal with the unique physical chancteristics of each sex.

The courts might decide, as they have in employment discrimination cases under Title VII of the Civil Rights Act, ${ }^{40}$ to supplement this rule of identical treatment with safeguards against more subtle forms of discrimination. Thus intelligence tests would have to be carefully scrutinized to insure that they are actually testing general intelligence -or skills specifically needed by the military-rather than a familiarity with male-oriented items in our present culture. ${ }^{50} \mathrm{High}$ physical standards or skill requirements which eliminated a large proportion of women might also be challenged as unnecessarily restrictive at a time when eighty-five percent of military jobs are noncombatant. ${ }^{31}$ With regard to such a challenge, the services and ultimately the courts would

48. See 118 CoNG. Rec. S 4390 (daily ed. March 21, 1972) (remarks of Senator Bayh): $[T]$ he first impact of this equal rights amendment as far as the military services are concerned would be to say that any woman who wants to serve her country will have the opportunity to do so, and will be either admitted or denied on the basis of the same grounds used to admit or deny men.

But see Speech by Frings, supra note 42, at 12-13, which suggests that the Amendment could be interpreted to permit the services to choose the most qualified men and women, adjusting the test standards and educational qualifications in order to get enough men and enough women for their particular needs. This view would not require that the standards be identical for both men and women, but would instead allow the military departments to pick the "cream of the crop" among both men and women applicants. This interpretation is inconsistent with the ER.A's basic premise that judgments must be based on individual characteristics rather than the perceived characteristics of an entire sex group. See note 23 supra.

The requirement of individualized selection would also invalidate distinctions based upon sex-role generalizations. For example, the special waiver requirement for women with dependent children could not be justified by either the observation that mothers spend more time with young children than fathers or the judgment that they ought to do so.

49. 42 U.S.C. $\$ 2000 \mathrm{e}(1970)$.

50. See Brown, Emerson, Falk \& Freedman, supra note 13, at 971. For cxample, the Armed Forces Qualifying Test is presently being revised because it was found to be male oriented. Interview with Col. Bette Morden, Special Issistant to the Director of the WWAC, Washington, D.C., Dec. 6, 1972. (Col. Morden retired on Dec. 31, 1972.) B); stressing areas, such as mechanics, which are unfamiliar to many women, the test eliminates qualified women. On the other hand, a test specifically designed to examine an applicant's skill in a particular field would be legitimate under the ER.1, if narrowly drawn to fit the needs of the services.

Courts have already struck down allegedly "race-ncutral" tests and educational requirements which were found to be discriminatory in effect. See Griggs v. Duke Power Co., 401 U.S. 424 (1971); Hicks v. Crown Zellerbach Corp., 319 F. Supp. 314 (E.D. La. 1970); Broussard v. Schlumberger Well Services, 315 F. Supp. 306 (S.D. Tex. 1970). See also Quarles v. Phillip Morris, Inc., 279 F. Supp. 505 (E.D. Va. 1968) (holding unlawful a seniority system neutral on its face which perpetuated the effect of an emplojer's past discriminatory acts).

51. 118 CoNG. Rec. S 4390 (daily ed. March 21, 1972). 
have to determine whether the legitimate needs of the military justified the maintenance of standards that barred virtually all women from the substantial educational and vocational opportunities in the armed forces. ${ }^{52}$

\section{Officer Procurement}

With undisguised bluntness the military services discriminate against women in the procurement of officers. Female applicants to the Army Officer Candidate School (OCS) are required to have completed two years of college, whereas male applicants need only have a secondary school education. ${ }^{53}$ Direct appointments to a number of positions in the Navy and Marines are statutorily restricted to males. ${ }^{54}$ Custom and regulation prohibit women from being considered for admission to the three major military academies, ${ }^{55}$ even though they are not barred by statute. ${ }^{56}$ Finally, the military's ROTC program was until recently completely closed to women, ${ }^{57}$ and even now is available only on a limited, experimental basis. ${ }^{58}$

52. Cf. Griggs v. Duke Power Co., 401 U.S. 424 (1971) (Court sustained black employees' contention that an employer's requirement of a high-school cducation or passing of a standardized general intelligence test as a job condition violated Title VII, because neither of these requirements was related to the jobs in question); 2 CCH EMl'Lor. Prac. Guide $\S 6286$ (1971) (employer who applied a minimum-height rule to job ap. plicants of both sexes found to have violated Title VII of the Givil Rights Act, since evidence revealed that the height requirement would be satisfied by the averagc inale but by only twenty percent of the females and that such a requirement was not justificd as a business necessity).

53. House, Fact Sheet, Procurement of WAC Officers Compared with Procurement of Male Officers, on file with the Yale Law Journal. In addition, females must have a G.T. (mental) score of 115 as compared with a G.T. score of 110 for males.

54. 10 U.S.C. $\$ \S 5575,5576,5577,5587$ (1970). These restricted career areas in the Navy are the Supply Staff Corps, the Chaplain Staff Corps, the Civil Enginecr Staff Corps, and officers designated for engineering, aeronautical engineering, and special duty. Women in the Navy and Marines also may not be limited duty officers. 10 U.S.C. $\S 5589(1970)$.

Women similarly are barred from the aviation cadet program, into which civilians and enlisted members of the Navy and Air Force can be commissioned. See 10 U.S.C. $\$ \S 6911,6913,8257$ (1970). The Navy has recently selected eight women for its aviation cadet program as "a test program established as a part of the Navy goal of equal rights and opportunities for women." N.Y. Times, Jan. 11, 1973, at 77, col. 1.

55. Interview with Col. Morden, supra note 50. Several Senators have nominated women for admission to the academies, see, e.g., 118 Conc. REc. S 4860 (daily cd. March $28,1972)$, but none has been accepted.

56. See 10 U.S.C. $\$ \S 4346,9346,69581$ (1970).

57. This restriction was by custom rather than by statutc. 10 U.S.C. $\$ \S 2102.11$ (1970) refers only to the admission of "persons" into ROTC.

58. A WAC ROTC program was initiated in September 1972 at ten colleges to test the effectiveness of ROTC as a procurement source for women officers. In conjunction with this program, twenty ROTC scholarships were to be made available to female students. Utilization Hearings, supra note 2, at 12449 (testimony of Gen. Bailey); Housc, Fact Sheet, supra note 53. The Air Force ROTC program for women began in 1969 and is now open to women at 156 of the 170 colleges with Air Force units. See The Lady is an Air Force General, AIRMan Magazine, Sept., 1971, at 45. There are presently 17 women enrolled in Navy ROTC at four colleges. See Speech by Frings, supra note 42 , at 15; N.Y. Times, Dec. 4, 1972, at 1, col. 3 . 
Under the ERA, officer candidacy requirements and methods for procuring officers would have to be identical for men and women. Although qualifications would not have to be standardized for all the services, the requirements for commissioning within each service would have to be the same for men and women, ${ }^{53}$ and no path could be closed to either sex. For example, both the proponents ${ }^{60}$ and the opponents ${ }^{61}$ of the Amendment have asserted that its passage would require the service academies to admit women on an equal basis with men. ${ }^{62}$

\section{B. Fitting In}

\section{Structure of the Services}

The Army is organized into a number of functional units, such as the Infantry, the Medical Corps, and the Corps of Engineers, all of which are open to men. Women, on the other hand, are restricted to a single unit, the WACs, although they may be temporarily detailed to other units. ${ }^{63}$ The other services do not have separate women's corps per se, but they still handle women separately for a number of administrative purposes. ${ }^{64}$ For example, in the Marines, if there are

59. Thus the Army could either raise its OCS educational standard to meet those presently applicable to women only, or lower the requirement to a secondary education for everyone.

60. See Hearings, supra note 12, at 86 (remarks of Congressman Mitiva):

[I]s it really that shocking or radical a notion to think that maybe women ought to be allowed into the service academies if they want to go? If we accept the notion that there are and ought to be women officers in our various branches of the service, why should they not be allowed to go to the school of their choice in terms of the training they want to obtain for their service to their country? See also id. at 275 (testimony of Dr. Bernice Sandler); id. at 50 (remarks of Congress. woman Griffiths).

61. See 118 Conc. Rec. S 4575 (daily ed. March 22, 1972) (remarks of Senator Ervin, indicating that Professors Kurland and Freund joined him in this vicw).

62. The Directors of Women in each of the services have defended the sexual segregation of the academies on a variety of grounds: They argue that a sufficient number of qualified women are acquired through other procurement sources, that the academies are geared to combat from which women are excluded, and that integration would not be economically worthwhile. See, e.g., Utilization Hcarings, supra note 2, at 12471, 12493 (testimony of Capt. Quigley); id. at 12496 (testimony of Gen. Bailey); id. at 12471 (testimony of Gen. Holm).

These considerations, however, would not suffice to prevent integration. Under the Amendment, no mere state interest, such as administrative conienience or fiscal necessity, could justify a sex classification, see p. 1535 supra, and combat could not be wholly closed to women, see pp. $1550-52$ infra. Furthermore, a recent study by the . Air Force found that there exists no significant economic impediment to the sexual integration of the Air Force Academy. Interview with Gen. Holm, Dircetor of Women in the Air Force, Washington, D.C., Dec. 6, 1972. General Holm has concluded that the continued segregation of that facility derives more from a lack of commitment to the uraining of women leaders than to any of the arguments listed above.

63. 10 U.S.C. $\$ 3071(1970)$.

64. Speech by Frings, supra note 42, at 21. See also TASs Force RErozt, supra notc 2, at B-26. 
an appreciable number of women at one base, a separate women's company will be created within a battalion. ${ }^{65}$

Under the ERA the WACs and all other remnants of separate women's corps would have to be eliminated. ${ }^{60}$ Although the Supreme Court has never found sexually "separate but equal" facilities to violate the Fourteenth Amendment, such facilities would be impermissible under the ERA. The proponents of the Amendment have pointed out that the separate treatment of two groups, one of which has previously been treated as inferior by the law, can never in fact be equal. ${ }^{67}$ Moreover, separation by sex is indisputably classification by sex-and that is forbidden by the ERA. ${ }^{68}$

Congress evidently did not intend, however, that sexual integration encompass integrated living facilities. The legislative history shows that the constitutional right to privacy was thought to permit the military to maintain separate living quarters for men and women, so that they would not be forced to undress or perform personal functions in the presence of the opposite sex. ${ }^{60}$ This argument is dependent on two unsettled legal conclusions: that the right to privacy protects

65. Interview with Colonel Sustad, former Director of Women Marincs, Washington, D.C., Dec. 5, 1972 (Col. Sustad retired on Jan. 30, 1973).

66. When questioned by the House Appropriations Committec, the Judge Advocate General of the Army commented on the effect that the ERA would have on the structure of the WACs:

The primary function of maintaining a separate Women's Army Corps will probably be eliminated. Whether those distinctions based on sex that would remain permis. sible under the amendment will be continued through a separate label for female members is primarily a question of policy. However, the impact of the equal rights amendment, in my opinion, will so limit the permissible distinctions that it would be inaccurate to designate female members as belonging to a scparate corps, as that term is used to designate separate branches within the Army.

Reprinted in Speech by Frings, supra note 42, at 21-22.

67. See Brown, Emerson, Falk \& Freedman, supra note 13, at 902-03; Emcrson, In Support of the Equal Rights Amendment, supra note 14, at 231.

Congresswoman Martha Griffiths recognized the inadequacy of a dual system:

I am not for "separate but equal" because there is no such thing. The "scparate but equal" schools that we were sending blacks to were not equal. The "separate but equal" schools that you are sending women to are not equal.

Hearings, supra note 12, at 47. Dr. Bernice Sandler observed that sex-segregated col. leges, particularly when operated by the same governing body, are reminiscent of racesegregated facilities. Id. at 272 .

The case law under the Fourteenth Amendment has been mixed. Compare Kirstein v. Rector \& Visitors, 309 F. Supp. 184 (E.D. Va. 1970) and Bray v. Lec. 397 F. Supp. 934 (D. Mass. 1972) with Williams v. McNair, 316 F. Supp. 134 (D.S.C. 1970).

68. "The law may operate by grouping individuals in terms of existing claracteristics or functions, but not through a vast overclassification by sex." H.R. REP. No. 92.950, supra note 21 , at 6 (Separate Views). See note 29 supra.

69. See 117 CoNG. Rec. H 9368 (daily ed. Oct. 12, 1971) (remarks of Congressman Ryan): An argument which has been made against the original language of the equal rights amendment is that it would violate common sense and public standards by pro. hibiting the separation of sexes in the sleeping quarters of such public institutions as coeducational colleges, prisons, and military barracks .... The constitutionally guaranteed right to privacy affords grounds for reasonable scparation of the sexes in these instances.

See also Hearings, supra note 12, at 290, 404; note 23 supra. 
individuals from the embarrassment that would result from forced cohabitation and that the right so interpreted extends to military personnel. ${ }^{70}$ Neither conclusion, however, is unreasonable. First, the Ninth Circuit has held that the Fourth Amendment privacy right encompasses "[t]he desire to shield one's figured [sic] from view of strangers, and particularly strangers of the opposite sex . . . ."71 Second, while the military may legitimately deprive its personnel of much of the privacy guaranteed to civilians, such deprivations must always be justified by compelling interests of discipline or morale." Since living quarters are now segregated throughout the military, it is unlikely that the services would assert, or the courts declare, that the protection of sexual privacy through such an arrangement contravenes the doctrine of military necessity. Thus the courts would be justified in validating Congress' conclusion that the right to privacy, when balanced against the ERA, would permit the limited separation of the sexes for sleeping and toilet purposes. ${ }^{i 3}$ The precise degree to

70. For an examination of the similar assumptions bchind Congress' conclusion that prison sleeping areas could be kept segregated, see Note, supra note 10, at 1259 n.157.

71. Ford v. Story, 324 F.2d 450, 455 (9th Cir. 1963) (police officer held to have violated the Fourth Amendment right of $a$ woman who had come to the police station to report an assault. Over her objection, the officer had taken photographs of her in the nude and circulated them among the police personncl at the station. The court stated that "[w]e cannot conceive of a more basic subject of pribacy than the naked body," the shielding of which is "impelled by elementary self-respect and personal dignity." Id. at 455). Although the right to privacy is arguably broad cnough to cncompass all such serious intrusions upon basic human dignity, see Bloustcin, Privacy as an Aspect of Human Dignity: An Answer to Dean Prosser, 39 N.Y.U. L. REv. 952 (1964), the courts have been well advised to procecel cautiously, with an cye to the established doctrines surrounding the express constitutional provisions from which the privacy right was derived. See Ely, The Wages of Crying Wolf: A Comment on Roe v. Wade, 82 YALE L.J. 921 (1973). In this regard, it should be noted that the right to segregated sleeping quarters propounded by Congress is the closest corollary in the military context to the privacy of home and sexual relations already protected by" Supreme Court decisions. See cases cited in note 18 supra; Stanlcy v. Georgia, 394 US. 557 (1969).

72. See pp. 1537-39 supra. A finding that the right to privacy bars forced cohabita. tion in military housing would not require the services to provide individual bedrooms and showers for every soldier. For one thing, there is no reason to believe that forcing men and women to disrobe in the presence of the same sex violates the "clementary self-respect and personal dignity" shiclded by the right to privacy. See note 71 supra \&: p. 1546 infra. Mloreover, it could probably be shown that the provision of individual living quarters, at least in basic training and combat situations, would scriously jeopardize the preparation and utilization of an effective fighting force, in violation of the doctrine of military necessity. See pp. 1547 \& $1551-52$ infra.

73. Since privacy is an individual right, the possibility of waiver raises special prob. lems. Presumably, if a group of service personnel waived their right to be housed separately, the Equal Rights Amendment would require that they be assigned quarters on the basis of sex-neutral criteria, which might result in voluntary coeducational sleeping facilities. While the content of the privacy right may be determined by reference to societal mores, such mores in the absence of the privacy right are not of constitutional dimension and cannot be used to defeat the Amendment's ban on sex classifications. See note 23 supra. However, it is possible that individual rights which require detailed government regulation-such as the rights to privacy and the equal protection of the laws in the military, public school, or prison context-cannot be waired. 
which entire housing facilities could be kept separate is not clear, ${ }^{74}$ but Professor Emerson has suggested that courts and administrntors may look to the current mores of the community regarding relations between the sexes in determining the scope of the privacy exception. ${ }^{75}$

\section{Basic Training}

All enlisted recruits receive some form of basic training before being trained in their occupational specialties. In each of the services such training for males stresses discipline and physical development, while that of women is focused on administrative subjects. ${ }^{70} \mathrm{~A}$ similar disparity characterizes officer basic training. ${ }^{77}$ Moreover, training units are sexually segregated, ${ }^{78}$ frequently at different bases..$^{70}$

These differences undoubtedly reflect the disparate utilization of men and women in the military. After ratification of the ERA the services would still be permitted to adapt basic training to probable later assignments if they so desired, but placement in a particular training program could not be based on an overbroad sex classification. ${ }^{80}$ In other words, a man and a woman would have to receive identical basic training, unless an examination of the individual physical capability or assignment potential of each dictated different pro-

74. In planning housing facilities the military could follow the model of universitics which have established coeducational dormitories, while maintaining the right to privacy by designating separate floors or separate parts of the same building for cach of the sexes. See Hearings, supra note 12, at 274 (testimony of Dr. Sandler).

75. Brown, Emerson, Falk \& Freedman, supra note 13, at 902 . This conclusion is not unreasonable in light of the fact that social traditions and mores have been used to determine the very existence of the right to privacy. See Roe v. Wade, $93 \mathrm{~S}$. Ct. 705, 795 (1973) (Stewart, J., concurring); Griswold v. Connecticut, 381 U.S. 479, 493 (1965) (Goldberg, J., concurring).

76. In the Army women are trained in professional development (benefits of military service, community services, leadership, personnel policies, etc.) but are not trained to be "traditional" military professionals. Watson, Fact Sheet, supra note 39. Although physically qualified, see note 45 supra, they do not take long marches or utilize their hand-to-hand combat potential. The closest that WACs come to combat training is two days of field training that "has the air of a well-disciplined group of girl scouts on a camp-out." Phillips, On Location with the WACs, Ms., Nov., 1972, at 62. In the Navy shipboard organization and rugged physical training are excluded from the female program. Interview with Captain Quigley, Assistant Chief of Naval Personncl for Women, Washington, D.C., Dec. 5, 1972. Instruction for women in the Marincs includes subjects such as the application of make up, how to avoid trouble, and how to wcar a uniform. Interview with Colonel Sustad, supra note 65. Air Force training follows a similar pattern. Intervicw with General Holm, supra note 62.

77. Interviews with Colonel Sustad, supra note 65, and Captain Quigley, supra note 76.

78. See, e.g., Interview with Colonel Sustad, supra note 65; Priem, Fact Shcet, Ex: pansion of the Women's Army Corps, on file with the Yale Law Journal. Continental Army Command (CONARC) is currently studying a proposal to shorten the WAC Of. ficer Basic Course from eighteen to nine weeks, after which the WAG officer would attend the basic officer course of one of the male branches. Pricm, Fact Shcet, supra. The Air Force officer program already permits some mingling of the sexes during periods not set aside for physical training. Interview with General Holm, supra note 62 .

79. See note 39 supra.

80. See p. 1550 infra. 
grams. A few differences in the physical training of all women might be justified by the unique physical characteristics of the sexes, but such differences would have to correlate closely with the characteristics in question and could not be based on the generalization that women are weaker than men. ${ }^{81}$

Although the nature of the training given men and women would thus have to be almost identical, the training units themselves could still be segregated to the limited extent required by military necessity and privacy. The services might argue that discipline and teamwork cannot be instilled in the basic trainee unless the unit with which he sleeps remains discrete and sexually segregated throughout the training period. ${ }^{82}$ The burden would be on the military to prove that such separate but equal training units ${ }^{53}$ are essential to the discipline and effectiveness of the armed forces. ${ }^{84}$ The right to privacy would only demand that sleeping and bathroom facilities be kept separate, which could be accomplished through segregated barracks or perhaps only separate sections or floors within a single building. ${ }^{85}$

\section{Occupational Specialties}

The military occupational classification (MOS) system is designed to identify, classify, and relate skills and personality characteristics to military job requirements. ${ }^{86}$ In the Army women are specifically excluded from those MOS associated with combat, close combat support, hazardous duty, and strenuous physical activity, as well as those that would require their assignment to an isolated area. ${ }^{87}$ As of July

81. Brown, Emerson, Falk \& Freedman, supra note 13, at 893.94.

82. This claim might be based on a perceived critical need for intensise group interaction and for depriving trainees of the company of the opposite sex.

83. Under the less drastic means analysis, see note 35 supra, separation of the sexes would be limited to the smallest unit necessary to satisfy the requirements of privacy and discipline.

84. See note 114 infra.

85. See p. 1546 supra.

86. For example, factors that are to be considered in the training classification of an individual in a particular MOS in the Army are: (1) needs of the Army, (2) cxisting grade and MOS imbalances (both local and Army-wide), (3) budgetary or traicl re. strictions, (4) medical condition and physical limitations, (5) enlisted commitments, (0) training and experience (both civilian and military), (7) education, (8) test scores, (9) preference of individual, (10) avocation and hobbies, and (11) normal pattern of carcer progression. GAO, Improper Use of Mfilitary Personnel (197I), reprinted in Utilization Hearings, supra note 2 , at 12410 .

87. Morden, Fact Sheet, WAC Utilization, Aug. 15, 19\%2, on file with the Yale Law' Journal. Out of a total of 482 enlisted MOS, 434 are abailable to women. Id. Until Augtist 1972, only 140 MOS had been open to women. The integration of women into these areas has been slow. Interview with Col. Arorden, supra note 50 . The only positions which are closed to men are WAC Commander, WAC reeruiter, and certain jobs in the medical field involving the care and treatment of female patients. Utilization Hearings, supra note 2, at 12443 (testimony of General Bailey). 
1972, medical and dental specialties and administrative personnel accounted for the occupational specialties of 94.6 percent of the enlisted women in that service. ${ }^{88}$ Similarly, women are excluded from more than half of the army officer MOS. ${ }^{89}$

Although the "Navy's intrinsic mission [is] as a seagoing operating force," 90 women cannot be assigned to duty on naval vessels other than hospital ships and transports. ${ }^{.1}$ Furthermore, sea duty or even "eligibility for command at sea" is often an important qualification in the selection for officer shore assignments. ${ }^{22}$ Finally, the "restricted line," a broad officer classification encompassing the more technical occupational specialties, is statutorily closed to women..$^{03}$ As a result of these restrictions, Navy women are concentrated in personnel jobs..$^{04}$

Enlisted women Marines may serve on an interchangeable basis

88. TASK Force Report, supra note 2, at 26. Prior to July 17, 1972, women generally enlisted in the Administrative, Supply and Medical Fields. Women can now enlist for the following additional career fields: air defense missiles, wire maintenance, precision devices, textile and leather repair, automotive maintenance, motor transport operator, printing, law enforcement, and radio code. Since July 17, approximately twenty-five women have enlisted in these new career fields. The Army anticipates that with more publicity many more women will enlist in these areas that had been exclusively male career fields. Elder, Fact Sheet, Career Field Enlistments, Aug. 7, 1972, on file with the Yale Latw Journal.

89. The total number of officer MOS in the Army is 365 . Of the 188 from which women are excluded, eighty-one are medical officer MOS, thirty-five are male command MOS, forty-nine involve railroad, marine, or aviation operations, and twenty-three others involve strenuous physical labor or assignment to a combat or hazardous duty area. Morden, Fact Sheet, supra note 87. As a result, forty-six percent of the women now serving as army officers are in the field of administration and personnel, whilc another 14.3 percent are in positions commanding other women. One of the MOS from which women are excluded is Post Commander. Women command organized WAC units consisting of approximately 100 women. Groups of less than fifty women at a station are called WAC contingents and are administered and commanded by men. Morden, Fact Sheet, supra note 87. Some classifications are particularly obtuse: women may be milltary police officers, but not correctional officers. Numerical List of Occupational Specialties, Section III, C31, AR 611-101, June 13, 1972, on file with the Yale Law Journal.

90. Utilization Hearings, supra note 2, at 12455 .

91. 10 U.S.C. $\$ 6015$ (1970). Women have served aboard Navy ships only with medical staffs on hospital vessels and transports belonging to the Military Sealift Command. Washington Post, Feb. 15, 1972, at A3, col. 5. Admiral Zumwalt's Z-gram 116, CNO msg 0711152 Aug. 72, noted that a limited number of officer and enlisted women werc being assigned to the regular ship's company of the U.S.S. Sanctuary, a recommissioncd hospital ship, as a pilot program. Although Z-gram 116 also authorized "limited" entry of enlisted women into all ratings, the statutory prohibition against assigning women to combat ships still exists, so that actual assignment policies are unclear.

92. NR.0836 (1948) states that "the officer detailed as Commandant of a naval district shall be an officer of the line in the Navy eligible for command at sca." "Thus women officers, whose career patterns should qualify them for just such leadership as. signments, are arbitrarily excluded. Denby, Command Opportunity and Flag Grade for Women Officers, June 19, 1972, at 23-24 (unpublished thesis at U.S. Naval War College).

93. See note 54 supra. Theoretically, women in the "unrestricted line," encompassing most other officer assignments, can be designated for temporary duty in a restricted line community not involved in sea duty.

94. Coye, supra note 5, at 12484, citing Bureat of Naval Personnel Computer Printout, April 29, 1971. Commander Denby concluded after studying the opportunities for fe. male officers that there was "irrefutable evidence that women officers have stagnated in a relatively limited number of career paths primarily in administrative arcas." Denby, supra note 92 , at 61 . See also Coye, supra note 5, at 12476. 
with men in about two-thirds of the enlisted Marine MOS. Women Marine officers are also restricted to two-thirds of the available MOS fields. ${ }^{96}$ Moreover, a regulation specifically states that women officers may succeed to command only over those activities which have the administration of women Marines as their primary function. ${ }^{97}$

By contrast, only five officer career fields in the Air Force are closed to women, and these are all associated with aircraft which might be engaged in combat missions. ${ }^{98}$ However, half of the male officers are concentrated in the pilot and navigator categories, ${ }^{09}$ which are two of those closed to women as a matter of Air Force policy. ${ }^{100}$ The number of specialty fields open to enlisted women has recently been expanded, but few women have yet been assigned to these new fields. ${ }^{101}$

The primary reasons for the exclusion of women from various occupational fields, whether by law or regulation, are physiological and cultural. Some jobs are considered to be beyond the physical capabilities of women. ${ }^{102}$ Others, most notably combat and sea duty, ${ }^{103}$ are simply thought to be male activities. ${ }^{104}$ Since women have proven

95. Utilization Hearings, supra note 2, at 12462 (testimony of Coloncl Sustad). Thirtcen of the thirty-six enlisted MOS are completely closed to women. Limited duty and combat ship assignments are also closed to women Marines. See notes 54 \& 91 supro.

96. Utilization Hearings, supra note 2, at 12461 (testimony of Colonel Sustad). The twenty-three MOS available to female officers are not the same as the twenty-three considered suitable for enlisted women. For cxample, enlisted female personnel may be trained in logistics, but officers may not; officers may be in the Supply Services, but enlisted women may not.

97. Interview with Colonel Sustad, supra note 65.

98. I0 U.S.C. $\$ 8549$ (1970) prohibits the Air Force from assigning women to duty in aircraft engaged in combat missions.

99. Interview with General Holm, supra note 62.

100. Id. Thus, as in the Navy, women "airmen" are excluded from one of the primary missions of the branch of the service of which they are considered full members.

101. Although, as of June, 1971, ninety-cight percent of enlisted career fields were technically open to women, TASK FORCE RErORT, supra note 2, at 25, as of July of the following year three-quarters of enlisted women were still administrative specialists and clerks. $I d$. at 26.

102. The Air Force excludes women from such jobs as telephone lineman for this reason. Utilization Hearings, supra note 2, at 12451 (testimony of General Holm).

103. When asked about the justification for restricting women from seagoing positions, Captain Quigley replied:

I would say first of all that you have to look at the sociological picture, and I do not think that this country, socictally speaking, is ready for women soiling sub. marines under the sea and commanding airemaft carriers across the waters.

Id. at 12495. See also id. at 12469 (testimony of General Bailey).

104. These justifications parallel those that have long been asserted in defense of occupational exclusion in other areas of employment. Under the Fourtecnth Amendment and Title VII of the 1964 Civil Rights Act, the courts have outlawed exclusionary cmployment practices based on such sexual stereotypes. See, e.g., Phillips v. Martin Mariclta Corp., 400 U.S. 542 (1971); Bowe v. Colgate-Palmolive Co., 416 F.2d 711 (7th Cir. 1969); Weeks v. Southern Bell Tel. \& Tel. Co., 408 F.2d 228 (5th Cir. 1969): Ridinger v: General Motors Corp., 325 F. Supp. 1089 (S.D. Ohio 1971); Cheatwood v. South Central Bell Tel. \& Tel. Co., 303 F. Supp. 754 (M.D. Ala. 1969); Rosenfeld v. Southern Pacific Co., 293 F. Supp. 1219 (D.C. Cal. 1968); Sail'er Inn v. Kirby, 5 Cal. 3d 1, 485 P.2d 529. 95 Cal. Rptr. 329 (1971). See generally Note, Developments in the Law-Employment Discrimination and Title VII of the Civil Rights ACl of 1964, 84 HaRv. L. REv. 1109 (1971). 
their usefulness as administrators and personnel officers, the services may also feel that they are needed to provide a skilled continuity base. ${ }^{105}$ Finally, women may be excluded from some training programs because, in the places where that skill is needed, a woman cannot be sent for other reasons. ${ }^{100}$ Most revealing is the attitude that women would serve in a much larger number of service positions (as they did during World War II) if there were a national emergency. ${ }^{107}$

Under the Amendment all occupational specialties would have to be open equally to men and women. The basic principle of the ERA that the law must deal with individual attributes means that sex would be an impermissible factor in determining the selection of a career field. The principle enunciated in the Congressional Reports is echoed throughout the testimony and debates: Particular women may be barred from jobs for which they are not fitted, just as particular men do not serve in those positions for which they are not qualified, but blanket prohibitions based on sex are impermissible. ${ }^{108}$

Application of the ERA to combat presents special problems, because countervailing constitutional provisions are of particular importance in this area. For example, it has been argued that the right to privacy might exclude women from at least some combat duty if sexually

Title VII provides that it shall be an "unlawful employment practice" for an employer engaged in an industry affecting interstate commerce, who has twenty-five or more employees, to "discriminate against any individual with respect to his compen. sation, terms, conditions, or privileges of employment, because of such individual's race, color, religion, sex, or national origin ...." 42 U.S.C. $\$ 2000 \mathrm{e}-2$ (a)(1) (1970). Although the statute's basic proscription against sex discrimination is absolute on its face, one significant qualification is included. The provisions do not apply "in those certain in. stances where religion, sex, or national origin is a bona fide occupational qualification reasonably necessary to the normal operation of that particular business enterprise . . .
42 U.S.C. $\$ 2000 \mathrm{e}-2$ (e) (1970). This "bfoq" test is similar to the Equal Rights $\Lambda$ mendment's "unique physical characteristics" exception. See Brown, Emerson, Falk \& Frecdmall, supra note 13 , at 926 .

105. Coye, supra note 5 , at 12480 .

106. Utilization Hearings, supra note 2, at 12486 (testimony of General Bailcy). These reasons include: (I) In an "emergency" it might be necessary to send the person filling a particular job slot to a combat area, and (2) housing or grade restrictions might preclude transfer of a woman to an area that requires a particular MOS.

107. Utilization Hearings, supra note 2, at 12445, 12467, 12486 (testimony of General Bailey); id. at 12502 (testimony of General Holm).

108. See, e.g., 117 Cong. REc. H 9369 (daily ed. Oct. 12, 1971); 118 Cong. Rec. S 4585 (daily ed. March 22, 1972); 116 CoNG. REC. 28005 (1970) (remarks of Congresswoman Griffiths).

In a speech to the American Bar Association, Rita Hauser, United States Representative to the United Nations Committee on Human Rights, discussed the effect of the Amend. ment on the military:

$I$ think that women should be judged in the same way as men. Some men makc soldiers and others don't. Some bang at the typewriters and some do bandage work and similarly women will be judged on their capabilities for being soldiers or otherwise and not on the basis of sex.

Reprinted in 118 ConG. REc. S 4374 (daily ed. March 21, 1972). 
segregated sleeping quarters could not be provided or enforced. ${ }^{100}$ While such considerations might justify the barring of one sex from a combat situation in which even minimal privacy is impossible, it would not justify a general reliance on sexually segregated combat units, much less the arbitrary exclusion of women from all combat duty. ${ }^{110}$ The purposes of the Amendment could not be thwarted by assertion of the economic and administrative burden of providing some separate facilities on field bases and warships.

Perhaps with reference to the doctrine of military necessity, Congresswoman Griffiths and Senator Bayh indicated that the final decision regarding the use of a particular woman in combat would be a military prerogative. ${ }^{111}$ One acceptable interpretation of these comments is that, taking into account the exigencies of battle, a commander in the field must be given broad discretion in deciding the role a given individual should play. ${ }^{112} \mathrm{~A}$ broader interpretation would permit the military to limit the assignment of women to certain combat positions as a matter of policy if it could be demonstrated that further integration would impair discipline and military effectiveness to such an extent that the ability of the troops to operate in a combat situation would be seriously affected. ${ }^{113}$ However, the military would be expected to test the effectiveness of integrated units in a variety of situations during the present peacetime environment and

109. Letter from Assistant Attorney General William Rehnquist to Representatise Don Edwards, Chairman of the Subcommittee on Constitutional Rights of the House Judiciary Committee, reprinted in Hearings, supra note 12, at 328.

110. The debate on Senator Ervin's proposed amendment to exempt women from combat duty, which was soundly rejected, see note 26 supra, reveals that several Senators contemplated that the ERA would require the assignment of women to front-line combat positions. See 118 CoNG. Rec. S $4395-4409$ (daily ed. March 21, 1972).

111. Congresswoman Griffiths stated:

The draft is equal. That is the thing which is equal. But once jou are in the Army you are put where the Army tells you where you are going to go.

S. REP. No. 92-689. supre note 2I, at 13. Senator Bayh commented that once in the service, a woman would be assigned to duty where her commanders thought she was qualified to serve. A commander would not need 10 send a voman into the front trenches if he felt that it would not be in the best interests of the combat unit to make such an assignment. 118 Conc. Rec. S 4390 (daily cd. March 21, 1972). Sec also S. REP. No. 92-689, supra note 21, at 14 (statement of Congressman Edwards).

112. A field officer in command of a squad or platoon must be allowed to utilize his or her soldiers as combat conditions dictate, without fear of constant judicial supervision. But such an officer, no less than one at the battalion or division level, would be barred from following a consistent pattern of sexual discrimination by catcgorically banning all women from certain combat positions.

113. The comparative effectiveness of women generally as combatants has been ques. tioned and is presently impossible to evaluatc. See Mead, A N'ational Service System as a Solution to a Pariety of National Problems, in THE DRAFT, A HAsDBoos of FActs \& Alternatrves 99, $107-09$ (S. Tax ed. 1967); Hale \& Kanowile, Women \& the Draft: A Response to Critics of the Equal Rights Amendment, 23 HAstivcs L.J. 199 (1971): Tiger, Male Dominance? Yes, Alas. A Sexist Plot? No., N.Y. Times, Oct. 25, 1970. \$ 6 (Magazine), at 124 . 
to produce empirical evidence establishing the necessity for any desired segregation to the satisfaction of the courts. ${ }^{114}$

\section{Moving Up}

\section{Although many statutory limitations on the promotion of women} to high ranking positions have been repealed, ${ }^{115}$ the proportion of such positions actually filled by women is far smaller than the proportion of women in the military as a whole.110 This discrepancy may be explained, at least in part, by continuing discrimination against women in promotion law and policy. ${ }^{117}$

114. The imposition of such a burden is justified by the fact that military fears concerning sexual integration could too easily be based upon impermissible assumptions about proper sex roles and the capabilities of women, which might be disproved over time in the face of successful performance by qualified women and the education of service personnel concerning the value of such integration. The government should thercfore be required to undertake experiments with sexual integration at all levels and to prove to the courts by clear and convincing empirical evidence that those levels that have not been integrated cannot be operated under such conditions because of the overriding requirements of military necessity.

A similar burden has recently been placed upon states which seck to provide different criminal sentencing schemes for male and female offenders. While such differential treatment was once routinely left to the discretion of the state, see Note, supra note 10, at 1245, several courts now require "substantial justification" for this sexual distinction, "empirically grounded to the greatest extent possible." New Jersey v. Costcllo, 50 N.J. $334,346,282$ A.2d 748, 755 (1971). See United States ex rel. Robinson v. York, 281 i. Supp. 8, 15 (D. Conn. 1968); Liberti v. York, 28 Conn. Supp. 9, 11, 246 A.2d 106, 107 (1968); Commonwealth v. Daniel, 430 Pa. 642, 243 A.2d 400 (1968).

115. Until 1967, WAC promotion to the grades of captain, major, and lieutcriant colonel could be made only to fill vacancies in those grades, whereas malc officers could be considered without regard to vacancies. 10 U.S.C. $\$ \$ 3299(\mathrm{f})$, (E) (1964), as amended, 10 U.S.C. \$ 3299 (1970). Also repealed at that time was Act of Sept. 2, 1958, 1'ub. L. 85-861, $\$ 1(80)(E), 72$ Stat. 1479 , which prohibited WAC reserve officers from being pro. moted above the grade of lieutenant colonel, and 10 U.S.C. $\$ 3215$ (1964), as amendel, 10 U.S.C. \& 3215 (a) (1970), which placed a two percent limit on the percentage which the prescribed authorized strength in female warrant officers bore to the total authorized strength of the Army in warrant officers. 10 U.S.C. $\$ 5462$ (1970) still gives the Secretary of the Navy power to prescribe the number of women officers who may hold appoint. ments in each grade above lieutenant junior grade in the Navy and above first lieu. tenant in the Marines.

116. See Utilization Hearings, supra note 2, at 12440 (testimony of Congressman l'ikc): There are roughly a million people in the Army of which [sic] only 19,000 are women, about one woman for every 80 men. There is one woman brigadier general for 255 Army brigadier generals, one woman colonel for 500 Army colonels, onc woman lieutenant colonel for every 190 Army lieutenant colonels, one woman major for every 120 Army majors, one woman captain for every 140 Army captains. Down in the realm of lieutenant, the women approach, but do not reach their proportionate share. The Army treats its women better than the Navy and the Air Force in terms of rank. There are still no female Major Generals.

See Special Subcomm. on the Utilization of Manpower in the Military of the House Comm. on ARmed Services, 92d CoNG., 2d Sess., Report H.A.S.C. No. 92-58, at 14660 (1972).

117. Only the Air Force has no separate promotion lists or quotas for men and women, yet even in that service there is a comparatively low number of fcmale officers. Air Force General Holm stated that the large ratio in the lower grades was "duc in large part to the expansion of the force in recent years," and that because of past pro. motion restriction there are few women coming up through the system who have the time in service and the grade necessary for promotion. Utilization Hearings, supra notc 2, at 12488-89; Telephone Interview with General Holm, Director Secretary of the Air Force Personnel Council, April 16, 1973. See Utilization Hearings, supra notc 2, at 12488 for a breakdown by sex of each rank in the Air Force. 
Although enlisted women compete with enlisted men for Army promotion, separate promotion eligibility lists are maintained for WAC officers. ${ }^{118}$ Navy and Marine enlisted women compete for promotion with their male counterparts in their skill specialty. ${ }^{119}$ Fe. males may not, however, be considered for selection as limited duty officers, ${ }^{120}$ an officer designation to which enlisted men who have served for a number of years in a specific technical field may be promoted. Navy and Marine women officers are considered for promotion through the rank of captain by separate selection boards. ${ }^{121}$ Although the selection boards for male officers continue to supervise promotion to the highest ranks, women may only be appointed above the grade of captain (to flag rank) by order of the Secretary of the relevant service, and then only when there is a position of sufficient importance and responsibility to warrant such a designation and it is determined that the person best qualified to fill that position is a woman. Moreover, any woman officer so appointed reverts to her permanent grade when she is detached from the flag position, ${ }^{122}$ although men retain their rank.

Since separate but equal treatment would be forbidden by the Amendment unless required by privacy considerations or military necessity, ${ }^{123}$ all vestiges of separate promotion systems would have to be eliminated, even if the military could demonstrate that the re-

118. Fact Sheet, WAC Promotion Policies, on file with the Yale Law Journal; 10 U.S.C. $\$ \$ 3283,3296,3311(1970)$. The Director of the W:ACs is not automatically appointed a lieutenant or major general upon selection, as are the chiefs of the various male corps, and she alone is statutorily said to serve "normally for not more than four years." Compare 10 U.S.C. \& 3071 (1970) with 10 U.S.C. \& 3036 (1970).

119. When Captain Quigley noted this fact at the Utitization Hcarings, Representative Pike replied that nevertheless:

If you are an enlisted man in the Navy you are six times as likely to be an E-6 as an E-1 [the lowest rank]. If you are an enlisted woman, you are more than twice as likely to be an E-I as an E-6. There are almost as many commanders in the Naby as there are ensigns, unless you're a woman, in which case there are three ensigns for every commander.

Utilization Hearings, supra note 2, at 12440.

120. 10 U.S.C. $\$ 5589(1970)$.

121. 10 U.S.C. $\$ 5764$ (1970), as amended by Pub. L. No. $90.130 \$ \$$ 1(19)(J). (K). 81 Stat. 378 (1967). The appointment and promotion of women officers are governed by laws separate from those dealing with male officers. See, e.g., 10 U.S.C. \$\$ 5703, 5704, 5760,5767 (c), 5771 (1970). A statute which specified the number of years a male officer in the Navy or Marines had to serve in one grade before he could be considered for promotion to the next higher grade was suspended by Exce. Order No. 11,437, 3 C.F.R. 142 (1968 Comp.), but a similar section pertaining to vomen officers has not been sus. pended. See 10 U.S.C. $\$ \mathbf{5 7 5 2}$ (1970). Another statute provides for the temporary promotion of officers in time of war or national emergency. Afale officers in the Navy in the grade of ensign or above and in the Afarines in the grade of sceond lientenant or above may be so promoted. Only female ensigns and second lieutenants may be promoted in this manner. 10 U.S.C. $\$ \$ 5787,5787(\mathrm{~b})(1970)$.

122. 10 U.S.C. $\$ 5767$ (1970), as amended by Pub. L. No. 90.130, \$ 1(19)(N), 81 Stat. 379. This applies to women in the grade of rear admiral in the Navy and major general or brigadier general in the Marine Corps.

123. See pp. 1544-45 supra. 
quirements for advancement were equal for each sex. ${ }^{124}$ It has been argued that these rules presently serve a valuable function, since women cannot fairly compete for promotion with men so long as they cannot serve in combat or command men. ${ }^{125}$ However, since the Amendment would modify or eliminate these discriminatory prohibitions as well, ${ }^{126}$ this justification need not immediately concern the courts.

\section{Getting Out}

Although recent statutory reforms included the repeal of a number of laws which provided for the involuntary retirement of women officers at an earlier age than men, ${ }^{127}$ remnants of these discriminatory provisions remain. ${ }^{128}$ In addition, service regulations provide that a woman may be terminated whenever it is established that she, whether married or single, is the parent of a minor child, is pregnant, has given birth to a living child while in military service, or has become a parent or stepparent of a minor child. ${ }^{120}$ To compound this in-

124. Cf. Loving v. Virginia, 388 U.S. 1 (1967) (Virginia's antimiscegenation law pro. hibiting interracial marriages held to violate the Fourtcenth Amendment's Equal Pro. tection Clause despite the fact that it affected the races equally).

125. Utilization Hearings, supra note 2, at 12500 (testimony of Colonel Sustad).

126. See pp. 1550-52 supra.

127. See, e.g., Act of June 30, 1960, Pub. L. No. 86.559, $\$ \$ 1(25)$, (27), 74 Stat. 272, repealed by Act of Nov. 8, 1967, Pub. L. No. 90-130, $\$ 1(12)(A)$, 81 Stat. 376: Act of Sept. 2, 1958, Pub. L. No. 85-861, \$ 1(94), 72 Stat. 1483, repealed by Act of Jutic 30 , 1960, Pub. L. No. 86-559, \& 1(22), 74 Stat. 271; Act of Sept. 2, 1958, Pub. L. No. 85.861, $\$ 1(192), 72$ Stat. 1535, repealed by Act of June 30,1960 , Pub. L. No. 86-559, $\$ 1(66)$, 74 Stat. 278; Act of Sept. 2, 1958, Pub. L. No. 85-861, \$1(192), 72 Stat. 1536, repealed by Act of Nov. 8, 1967, Pub. L. No. 90-130, $\$ 1(31)(A), 81$ Stat. 382.

128. Compare, e.g., 10 U.S.C. $\$ 3848$ (1970) with 10 U.S.C. \$ 3916 (1970) (Secretary of the Army may defer the required retirement of lieutenant colonels until age 60 for officers in five male corps but only until the thirtieth year of service for Rcgular $A$ rmy and WAC officers); Compare 10 U.S.C. $\$ 6398$ (1970) with 10 U.S.C. $\$ 6390$ (1970) (rctirement of Navy and Marine regular officers set at age 62 unless deferred until age 64 , but no deferment is provided for certain classes of women officers, whose retirement date is set at a sufficientiy short period of service to require retirement, in most cases, long before the age of 62 ).

129. Although the specific regulations vary from service to service, they are all based on Exec. Order 10,240, 3 C.F.R. 749 (1949-1953). In the Air Force, modifications lave removed the minor children provisions, allowed for cancellation of the discharge pro. ceedings if the pregnancy is terminated prior to a final determination by the discharge authority, and instituted a waiver of discharge provision to replace the virtually au. tomatic discharge under the initial regulations. AFR 40 (May 1, 1970), as amended, AFR 36-12(40) (March 1971). The Army, Navy and Marine Corps pregnancy regulations arc: AR 635-120 (June 9, 1971) (Army officers); AR 635-200 (June 21, 1972) (Army cnlisted personnel); NPM 3830160 (5) (April 1972) (Navy officers); NPM 3850220(2) (July 1, 1969) (Navy enlisted personnel); MCB 1900 (Jan. 28, 1972) (Marine Corps officers and enlisted personnel). There are, of course, provisions which allow for the discharge of male members, see, e.g., 10 U.S.C. $\$ \$ 3814,6292,6293,6294,6295,8814(1970)$, but none relate to the male's status as a parent.

The constitutionality of the Air Force pregnancy regulations has already becn chal. lenged under the Fourteenth Amendment. See Struck v. Secretary of Defense, 460 F.2d 1372 (9th Cir. 1972), cert. granted, 409 U.S. 947 (1972), vacated and remanded for con- 
equity, there is no provision for the payment of severance pay to regular officers in the Army and Air Force involuntarily discharged for pregnancy. ${ }^{130}$

Under the Amendment, retirement provisions within each service would have to apply equally to men and women. Retirement differentials based on specialty corps would be permissible, since the ERA would require integration of all such units. However, those provisions which allow extensions for male officers only would not survive.

Discharge policies would also have to be reformulated after passage of the ERA. The rules with regard to bearing or having a minor child would undoubtedly be eliminated, since their extension to men would virtually eliminate all career officers. Distinctions between single and married women who bear children would be permitted only if the same distinction were drawn between single and married men who father them.

Rules requiring discharge because of pregnancy present a special problem. ${ }^{131}$ Since pregnancy is a physical condition unique to women, the military would be permitted to enforce regulations which apply solely to pregnant women. However, such regulations must be narrowly drawn and not unduly harsh. A "problem" of legitimate concern would have to be identified (such as the danger of job-related injuries) and a sufficiently close relationship between the problem and the physical characteristic of pregnancy would have to be shown. ${ }^{132}$ The military would in every case have to select the alternative-e.g., transfer rather than discharge-that would have the least drastic ef-

sideration of the issue of mootness, 41 U.S.L.W. 3346 (U.S. Dec. 18. 1972) (upholding the relevant regulation); Robinson v. Rand, 340 F. Supp. 37 (D. Colo. 1972) (finding the relevant regulation unconstitutional). For a complete discussion, sce Note, Pregnancy Discharges in the Military: The Air Force Experience, 86 HAsv. L. REv. 568 (1973).

130. 10 U.S.C. $\$ 687$ (1970). W With certain exceptions, a nonregular officer involuntarily released after five or more years of continuous active military service is entitled to a readjustment payment of two month' basic pay for each jear of service. This payment is payable only to nonregular officers separated involuntarily for pregnancy. Gencral Holm reported that many young Air Force women decline to consider or accept regular appointments because of this rule. Utilization Hearings, supra note 2, at 12502.

131. The Supreme Court will soon have a chance to clarify the existing due process and equal protection limitations on pregnancy rules for government emplojecs. A series of lower court decisions, employing the uncertain degree of judicial scrutiny triggered by sex classifications challenged under the Fourteenth Amendment, are in substantial conflict, and the Court has granted certiorari in two of these cases. Compare Heath v. Westerville Bd. of Educ., 345 F. Supp. 501 (S.D. Ohio 1972) and La Flcur v. Cleveland Bd. of Educ., 465 F.2d 1184 (6th Cir. 1972), cert. granted, 41 U.S.L.W. 3569 (U.S. April 23, 1973), with Cohen v. Chesterfield County School Bd., No. 71-1707 (tih Cir. Jan. 15. 1973), cert. granted, 41 U.S.L.W. 3569 (U.S. April 23, 1973).

132. See note 17 supra. A court operating under the ERI night find appropriate a sex-neutral rule allowing any temporarily disabled serviceman or woman and his or her doctor to determine the duration and timing of leave. Sce Brown, Emerson, Falk \& Freedman, supra note 13 , at 929.32 . 
fect on the woman involved, ${ }^{133}$ treating pregnancy as any other temporary disability. ${ }^{134}$

\section{The Transition}

By expanding the opportunities for women and allowing them to reap the full benefits of military service, these major changes required by the ERA would confer benefits upon society as a whole as well as the women directly affected. Servicewomen would gain increased economic and social independence, and important educational and career opportunities. Equal job availability in all areas of employment, both public and private, would be stimulated as women lenrned traditional "male" skills, and the military would be able to serve as a symbol to the nation of the sexual equality sought by Congress. ${ }^{135}$

The difficulties accompanying these changes, though substantial, would probably be temporary. The integration of women into the armed services would undoubtedly parallel in many ways the far more sweeping integration of blacks undertaken in 1948. ${ }^{130}$ In that year the services were ordered to drop their racial quota systems and to administer all assignments and promotions on an equal merit basis. ${ }^{137}$ The Army in particular moved slowly in implementing these orders, with warnings of decreased efficiency and morale problems, but these fears proved largely unjustified. ${ }^{38}$ Although racial

133. The services have discharged, rather than transferred, women in this situation, justifying the decision on legitimate military necessity. According to the court in Rob. inson v. Rand, 340 F. Supp. 37, 40-41 (D. Colo. 1972) (finding unconstitutional the Air Force regulation requiring discharge for pregnancy), transfer constitutes a less drastic means for achieving the same basic purpose and must be used as an alternative to discharge.

134. For example, Air Force Manual 36-11 para. 3-13B, Jan. 29, 1971, provides for such a deferment when "a physical defect may be cleared within twelve months." "The regulation identifies this deferment as compatible with the military need for "readincss and effectiveness of the fighting force." Temporary medical leaves are also granted for a wide variety of ailments. See D.O.D. Directive No. 1300.11, Oct. 23, 1970; D.O.D. Memo. randum, Drug Abuse Control Program, July 12, 1972; D.O.D. Directive No. 1010.2, March I, 1972.

135. See Hale \& Kanowitz, supra note 24, at 207-20.

136. Exec. Order No. 9981,3 C.F.R. 722 (1948). The preamble to the order succinctly states the case for women also:

Whereas it is essential that there be maintained in the armed services of the United States the highest standards of democracy, with equality of trcatment and opportunity for all those who serve in our country's defense ....

137. Begeman, Air Force Tries Democracy, 122 New Republic, May 15, 1950, at 14.

138. See generally Kenworthy, The Case Against Army Segregation, 275 AnNALs of T11E Amer. Acad. of Polit. \& Soc. Scr. 27 (1951). See also Begeman, supra note 187, at 14.15, quoting E. H. Kenworthy, executive secretary of President Truman's Committec on Equality of Treatment and Opportunity in the Armed Forces:

Almost without exception, commanding officers stated frankly that, although they had recognized the merits of the new Air Force racial policy ... they had been apprehensive. Without any exception, they added that they were amazed with the ease with which the new policy had been effected and the absence of trouble. 
problems have not been eliminated in the services, the program of integration was largely successful and served as an important example to civilian society. ${ }^{139}$

Like the integration of blacks, which took six years to complete, ${ }^{140}$ the elimination of sex discrimination in the military cannot be expected to occur immediately. However, each branch of the service has already begun the task of reviewing its regulations and policies in order to comply with the ERA. ${ }^{141}$ Furthermore, the Amendment would not take effect until two years after ratification, which may itself take up to seven years to complete. ${ }^{142}$ This interim period, hopefully in a peacetime environment, should provide ample time for the transition. By combining the redrafting of laws and policies with an intensive educational program aimed at ameliorating friction and misunderstanding with regard to sex roles, ${ }^{143}$ the armed services should be able to comply with the Amendment's mandate for equality of opportunity and treatment within the military.

139. See Begeman, supra note 137, at 15, quoting Kenworthy, see note 138:

It was the opinion of some officers that this program could not but have an cffect, eventually, on civilian attitudes; that it was impossible for a white boy to live and work beside a Negro in basic training and in the technical schools without some real change taking place in his attitude toward race and racial equality.

140. 67 U.S. NeWS \&- WORLD REPORT, Sept. 1, 1969, at 26.

141. See note 4 supra.

142. H.J. Res. 208, 92d Cong., lst Sess., 117 Coxc. Rec. H 9392 (daily ed. Oct. 12, 1971); S.J. Res. 8, 92d Cong., 2d Sess., 118 CoNc. Rec. S 4612 (daily ed. March 22, 1972).

143. See Dell, The Black Soldier-A Situation Report, Sordiers, Feb., 1973, at 28, for a discussion of the efforts in the Army to promote racial harmony and influence behavior patterns. 